\title{
The Inner Navigation in First Nine Hundred (Northern Italy): Editorial and Geographical Aspects
}

\author{
Silvano Tozzo ${ }^{1}$ \\ ${ }^{1}$ Politecnico di Milano, Milano, Italy \\ Correspondence: Silvano Tozzo, Politecnico di Milano, Milano, Italy. E-mail: silvano.tozzo@polimi.it
}

Received: February 11, 2021

Accepted: October 21, 2021

Online Published: October 28, 2021

doi: $10.5539 /$ jgg.v13n2p1

URL: https://doi.org/10.5539/jgg.v13n2p1

\begin{abstract}
A brief excursion on the theme of inland navigation in the early twentieth century, resumed mainly by editorial references present both in the writ and in the appendices. The bibliographic indications, along with text, consent to frame the different facets of the matter. The titles reported, whose purpose is to corroborate (remark) what affirmed in the text, are grouped in consideration of content and type of publication.
\end{abstract}

Keywords: Geography, Navigation, Publishing

\section{Introduction}

In the first part of the twentieth century, the technical and periodical press, as well as the book press, shows a lively interest in a segment, transport, in expansion in the period considered. A verification in this sense can be perceived through the analysis of journal_indexes such as Journal of civil engineering department (1), The technical monitor (2), Civil engineering and industrial arts (3), to mention some of them. It is evident the attention with which contents of technical, geographical and economic nature are alternated returning an overall representation of the transformations taking place in mobility in its broadest (widest) sense.

The debate on inner navigation becomes consistent for the apparent gradual decrease, over time, of commercial traffic through the inland waterways and in general due to the low utilization of the hydrographic network formed by rivers and canals

The main reasons leading to what can be defined as underutilization of river itineraries are to search in the development of transport systems between nineteenth and twentieth century such as rail and road transport (motoring). And in the options related to the opportunity not to direct (allocate) resources for a sector not competitive in economic terms when compared to alternative mobility systems ("......in the eighties of last century the fluvial navigation was already losing in comparison with the railways").(4)

\section{Editorial and Geographical Analysis}

\subsection{Editorial Analysis}

Throughout the first part of twentieth century and until the sixties (though with less relevance approaching the middle of the century) the question on the advisability to restore (revitalize) the waterway network is remarked through the reproposition of various projects (appendix A) finalized to the redefinition of river itineraries evidently still (anyway) useful under the economic aspect.

Subsisted in fact the idea that, as had happened in northern Europe, also in Italy the river transport would have rendered extensive services to the development of agriculture and industry thanks to a reduction in transport costs of raw materials (5)

In the period considered here the editorial production on the argument is discreet, articles (appendix B) and monographs (appendix C) examine the relative problems and suggest solutions to bring to front also issues related to the territory and the infrastructures connected to navigable routes and potentially such.

The integrated analysis of navigation and relative hydrographic network through books and historical cartography presents different cultural solicitations First of all the comprehension of a system in transformation across technological innovation (6) and commercial policies affirming in the twentieth century. Not less attractive the geographic image strictly correlated to waterways itineraries, certainly a motive of interest to environmental and natural aspects. 
The text Lakes, rivers and navigable canals, published in the early years of the twentieth century, photographs the situation of inland navigation in the peninsula. The context represented is very realistic and offers an overview (accompanied by tables containing technical and commercial data) on the navigable network describing characteristics and potentiality As reported in the introduction (7) the book is published during a period of renewed interest on the matter by the institutions (appendix D). In effect the editorial initiative is promoted by the Ministry of public works with the collaboration of two engineers of the Civil engineering department. It is evident the attempt to recover a system destabilized by the lack of programming relative to investments and infrastructures that allows to glimpse the contrast existing between different realities (8).

Through the press of the epoch, the comparison with Europe denotes a lower capacity to use the waterway network also - in addition to the reasons already exposed - because of the inadequacy of rivers and canals in supporting boats with relevant loads.

\subsection{Geographical Aspects}

A careful examination of the graphic and cartographic material published in the early twentieth century, often enclosed to periodicals and monographs, allows the overall identification of the navigation system composed of Lakes, rivers and canals crossing the northern regions. Visible element in large-scale representations is the definition of a waterway network gradually denser in the final part of its route (Veneto-Emilia Romagna), continuation of the Lombardy part characterized by a different hydrographic and territorial organization. The graphic representation of the navigable ways of northern Italy depicted in figure 1 (published in 1905) describes the situation of practicable itineraries at the beginning of the century, classifying them in three classes defined by the degree of navigability of the watercourse (river-canal). A first consideration deriving from the analysis of the document regards the incidence degree of navigable watercourses, not very significant in relation to the general hydrographic network A second visible element is the density of navigable network detectable in the different regions, more attenuated between Piedmont and Lombardy, more articulated after Mantova up to the adriatic sea and therefore interesting _Veneto and Emilia.

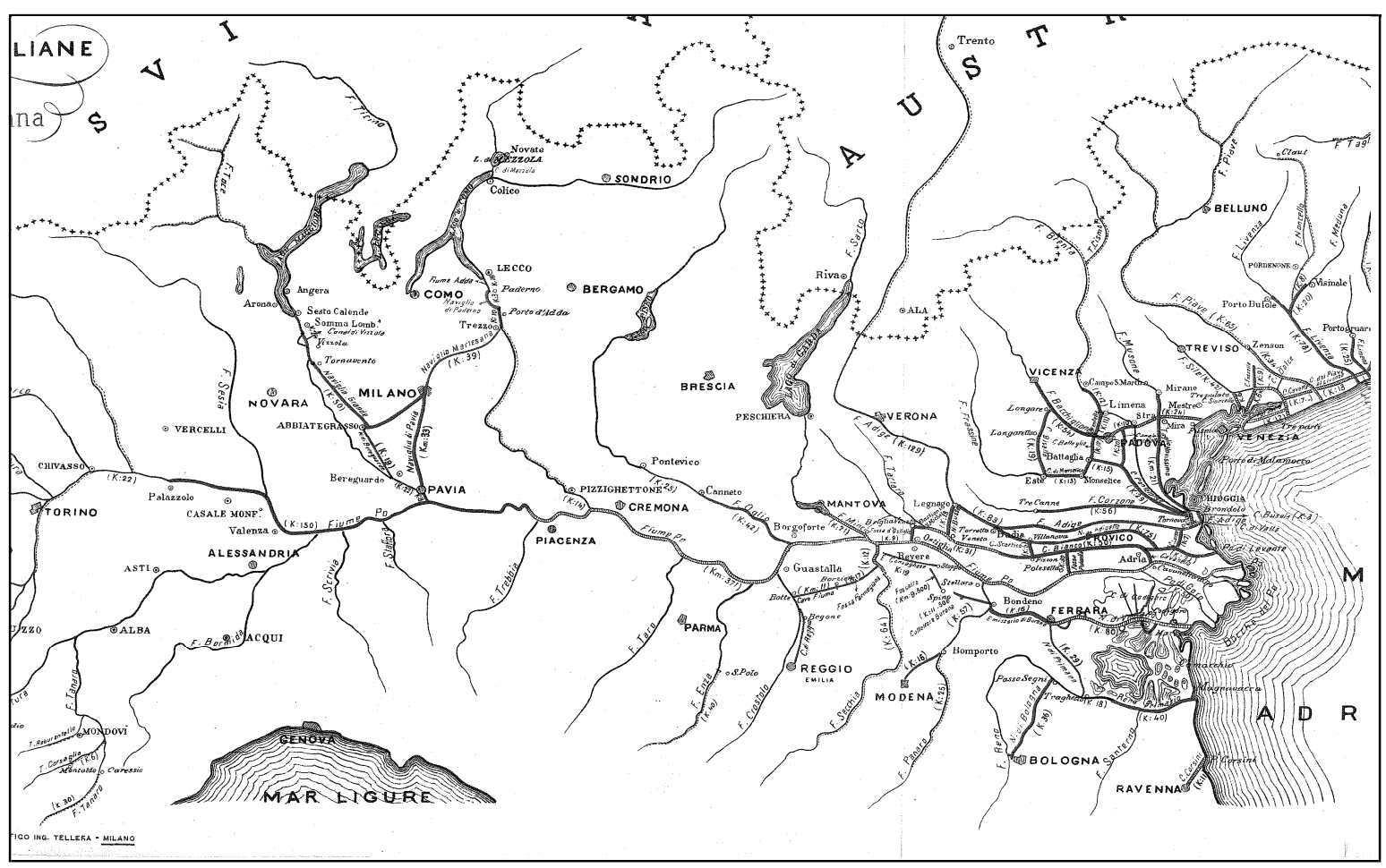

Figure 1.Waterways of northern Italy (1905) 
Effectively, the different natural and artificial waterways formed by rivers and canals describe a framework geographically complex (at least in northern Italy), therefore considered, in the first half of the twentieth century, a valid navigation system between cities and regions. The manifold projects presented over time as connection hypothesis between river routes characterized by low or good transit potentiality, have found space in the technical press without however, in most cases, be realized. The emerging image reveals a discrete sensitivity towards some geographic segments evidently perceived as pivotal itineraries. One of these is formed - from west to east in the triangle Sesto calende/Lecco/Pavia - almost completely by natural and artificial canals integrated by short sections (stretches) of the rivers Ticino and Adda. The Po river becomes the main axis (9) intended as primary connection within the itineraries integrated by its tributaries along the route to the adriatic sea. Therefore considered essential (the Po river) in a global project of revitalization of the inland waterway network.

\section{Final Considerations}

The short review presented here highlights some aspects - relative to the exploitation of the hydrographic network used for navigation - resumed by publishing in the first half of the twentieth century, following the debate that took place in those years. The analysis, in its partial and limited structure, proposes a concrete theme regarding a sector, transports, invested by a significant evolution in the period considered.

\section{References}

Bassi, G. (1985). Hydrography of Cremona province (Idrografia della provincia di Cremona). Cremona: Department of ecology, Province of Cremona.

Bigatti. G. (1999). The Po navigation between myth and history (18th and 19th centuries) (La navigazione del Po tra mito e storia (secoli XVIII-XiX)), in Boats and navigation of Po. History, practices, techniques, lexicon (Imbarcazioni e navigazione del Po Storia pratiche tecniche lessico), Bologna: CLUEB.

Lucca, D \& Passoni, G. (2008). Hypothesis of completion of Italian waterway system (Ipotesi di completamento del sistema idroviario italiano), in Fluvial-maritime logistics in Europe The european relevance of the adriatic corridor (Logistica fluvio-marittima in europa La rilevanza europea del corridoio adriatico), Milano: Franco Angeli, 39-44.

Ministry of public works. (1905). Lakes, rivers and navigable canals (Laghi,fiumi e canali navigabili). Milano: Pirola.

Palena, R. (1999). The Po.Navigation and navigability in the 20th century (Il Po. Navigazione e navigabilità nel $X X$ secolo) in Boats and navigation of Po. History practices techniques lexicon (Imbarcazioni e navigazione del Po Storia pratiche tecniche lessico), Bologna: CLUEB.

Passoni, G \& Soppracone, M. (2008). Navigation for goods transport in Italy (La navigazione per il trasporto delle merci in Italia), in Fluvial-maritime logistics in Europe The european relevance of the adriatic corridor (Logistica fluvio-marittima in europa La rilevanza europea del corridoio adriatico),Milano: Franco Angeli, 45-58.

Stocchi, S. (1991). Waterways in Lombardy (Vie d'acqua in Lombardia). Milano: Motta.

Ugolini, P. (1969). The technical-economic perspectives of the Po-Adriatic navigation axis (Le prospettive tecnicoeconomiche dell'asse di navigazione Po-Adriatico), in New transports for italian economy The navigation axis Po-Adriatico (Nuovi trasporti per l'economia italiana L'asse di navigazione Po- Adriatico), Milano: Giuffrè, 1-7.

Ugolini, P. (1969). The navigability of Po: backdrops and works of arrangement (La navigabilità del Po: fondali e opere di sistemazione) in New transports for the Italian economy The Po-Adriatic navigation axis (Nuovi trasporti per l'economia italiana L'asse di navigazione Po-Adriatico), Milano: Giuffrè, 9-20. 


\section{Notes}

Note 1. Journal of civil engineering department (Giornale del Genio civile),1863-1923, Roma

Note 2. The technical monitor (Il Monitore tecnico), 1894-1955, Milano

Note 3. Civil engineering and industrial arts (L'ingegneria civile e le arti industriali), 1875-1906, Torino

Note 4. Stocchi, S. (1991) p.81

Note 5. Palena, R. (1999) p.51

Note 6. Abruzzese, M (1897) An experiment of inland steam navigation between Venice and Milan (Un esperimento di navigazione interna a vapore fra Venezia e Milano), Roma: Voghera

Bernardis, C (1911) The first reversible internal combustion engines for navigation use built in Italy (I primi motori a combustione interna reversibili per uso di navigazione costruiti in Italia), Roma: Italian polygraphic workshop

Canavesio, S (1893) On the activation of inland steam navigation in northern Italy (Sulla attivazione della navigazione interna a vapore nell'alta Italia), Torino: Bona

Note 7 “.....In today's awakening that fortunately alludes to occur and in the government and in the public opinion around the importance of inland navigation....." (....Nell'odierno risveglio che fortunatamente accenna a verificarsi e nel governo e nell'opinione pubblica intorno all'importanza della navigazione interna...)

Note 8. Within the paragraph (p.11) Modes used for the exercise of navigation emerges the coexistence between realities anchored to the past "......The exercise of navigation....... is generally and in almost all cases carried out by means of boats with animal propulsion...." and more advanced situations ".....in various canals it is also extending, for some years, the towing of boats with steam or petrol ferries....."

Note 9. At the beginning of the century, of 3000 total $\mathrm{km}$ of navigable lines, 2200 are calculated in the Po network connection 


\section{Appendix A}

\section{Bibliography related to proposals and projects}

\begin{tabular}{|c|c|c|}
\hline $\begin{array}{l}\text { Anonymous society for } \\
\text { the foothill canal (Società } \\
\text { anonima per Il canale } \\
\text { pedemontano) (1926) }\end{array}$ & $\begin{array}{l}\text { The foothill canal of great navigation and the problem of inland } \\
\text { navigation in northern Italy (Il canale pedemontano di grande } \\
\text { navigazione e il problema della navigazione interna nell'Italia } \\
\text { settentrionale) }\end{array}$ & $\begin{array}{l}\text { Bergamo: Italian } \\
\text { institute of } \\
\text { graphic arts }\end{array}$ \\
\hline $\begin{array}{l}\text { Arimondi, C (Turin } \\
\text { Committee for inland } \\
\text { navigation) (1907) }\end{array}$ & $\begin{array}{l}\text { Studies for a navigable canal from Mediterranean sea to the Po } \\
\text { valley: Report (Studi per un canale navigabile dal Mar Mediterraneo } \\
\text { alla valle padana : Relazione) }\end{array}$ & Torino: Gili \\
\hline Beretta, M (1921) & $\begin{array}{l}\text { About an organic regulatory plan of the waterways of great } \\
\text { navigation in northern Italy (Di un organico piano regolatore delle } \\
\text { vie d'acqua di grande navigazione nell'Italia settentrionale) }\end{array}$ & Milano: Piccioni \\
\hline Bonini, C.F (1920) & $\begin{array}{l}\text { The inland navigation in Italy: considerations and proposals (La } \\
\text { navigazione interna in Italia: considerazioni e proposte) }\end{array}$ & Torino: Lattes \\
\hline Buizza, A (1911) & $\begin{array}{l}\text { The navigable canal from Lake Iseo to Brescia to Canneto sull'Oglio: } \\
\text { contribution to the study of inland navigation in the province of } \\
\text { Brescia (Il canale navigabile dal lago d'Iseo a Brescia, a Canneto } \\
\text { sull'Oglio : contributo allo studio della navigazione interna nella } \\
\text { provincia di Brescia) }\end{array}$ & $\begin{array}{l}\text { Brescia: } \\
\text { Apollonio }\end{array}$ \\
\hline Caldara, E (1918) & $\begin{array}{l}\text { The great inland navigation and the navigable line Milan-Venice (La } \\
\text { grande navigazione interna e la linea navigabile Milano-Venezia) }\end{array}$ & $\begin{array}{l}\text { Bergamo: Italian } \\
\text { institute of } \\
\text { graphic arts }\end{array}$ \\
\hline Candiani, L (1907) & Inland navigation: criteria and proposals for its implementation & $\begin{array}{l}\text { Milano: The } \\
\text { commercial press }\end{array}$ \\
\hline Capuccio, G (1905) & $\begin{array}{l}\text { Turin sea port: project for an inland navigation line between the } \\
\text { Adriatic and the Mediterranean (Torino porto di mare : progetto di } \\
\text { una linea di navigazione interna tra l'Adriatico ed il Mediterraneo) }\end{array}$ & $\begin{array}{l}\text { Torino: Roux and } \\
\text { Viarengo }\end{array}$ \\
\hline $\begin{array}{l}\text { Commission for inland } \\
\text { navigation (1910) }\end{array}$ & $\begin{array}{l}\text { Report by the Commissioner, Engineer Piola, on the project for a line } \\
\text { of inland navigation Lake Maggiore-Milan-Adriatic Sea with branch } \\
\text { from Mantova to Garda lake (Relazione del Commissario Ing. Piola } \\
\text { sul progetto per una linea di navigazione interna Lago } \\
\text { Maggiore-Milano-Mare Adriatico con diramazione da Mantova al } \\
\text { Lago di Garda) }\end{array}$ & Roma: Manuzio \\
\hline $\begin{array}{l}\text { Commission of Italian } \\
\text { railway engineers (1909) }\end{array}$ & $\begin{array}{l}\text { Considerations around the studies and the means to develop inland } \\
\text { navigation in Italy in relation to railways - Congress of Italian } \\
\text { railway engineers, Bologna } 1909 \text { (Considerazioni intorno agli studi } \\
\text { ed ai mezzi per sviluppare la navigazione interna in Italia in relazione } \\
\text { coll'esercizio delle ferrovie - Congresso degli ingegneri ferroviari } \\
\text { italiani, Bologna 1909) }\end{array}$ & $\begin{array}{l}\text { Roma: } \\
\text { Publishing } \\
\text { cooperative of } \\
\text { italian engineers }\end{array}$ \\
\hline Mongini, U (1900) & $\begin{array}{l}\text { Inland navigation project between the Po and the Volano (Progetto di } \\
\text { navigazione interna tra il Po ed il Volano) }\end{array}$ & Ferrara: Taddei \\
\hline Raddi, A (1917) & $\begin{array}{l}\text { Navigation of Arno and related projects and proposals (La } \\
\text { navigazione dell'Arno ed I relativi progetti e proposte) }\end{array}$ & $\begin{array}{l}\text { Milano: Book } \\
\text { publishing } \\
\text { company }\end{array}$ \\
\hline $\begin{array}{l}\text { Venice Committee } \\
\text { for inland navigation } \\
(1909)\end{array}$ & $\begin{array}{l}\text { Preliminary project for the arrangement of the navigable line } \\
\text { between Venice and Porto Nogaro: Report }\end{array}$ & $\begin{array}{l}\text { Venezia: Veneto } \\
\text { institute of } \\
\text { Graphic Arts }\end{array}$ \\
\hline
\end{tabular}




\section{Appendix B}

\section{Articles in technical journals}

(1895) Construction operation and administration of navigable rivers and canals at international inland navigation conferences held from 1885 to 1894 (Costruzione esercizio ed amministrazione dei fiumi navigabili e canali nei congressi internazionali di navigazione interna tenutisi dal 1885 al 1894) Civil engineering and industrial arts (L'Ingegneria civile e le arti industriali) 21 , p 158

(1892) Electric navigation (Navigazione elettrica) Journal of civil engineering department (Giornale del Genio civile) 21, p 374

(1917) For a canal Savona-Torino-Lake Maggiore (Per un canale Savona-Torino-Lago maggiore) Railway engineering (Ingegneria ferroviaria) XIV/11, p 128

(1907) For a navigable canal between Chioggia and the Po (Per un canale navigabile fra Chioggia e il Po) The technical monitor (Il Monitore tecnico) 13, p 550

(1917) For the construction of the fluvial port of Milan (Per la costruzione del porto fluviale di Milano) Railway engineering (Ingegneria ferroviaria) XIV/13, p 156

(1913) For the navigable line from Milan to Venice (Per la Linea navigabile da Milano a Venezia) The technical monitor (Il Monitore tecnico) 19

(1917) Funds, works, provisions for inland navigation (Fondi lavori provvedimenti per la navigazione interna) in Railway engineering (Ingegneria ferroviaria) XIV/10, p 116

(1913) For the improvement of the navigable line Lake Maggiore-Milan (Per il miglioramento della Linea navigabile Lago Maggiore-Milano) The technical monitor (Il Monitore tecnico) 19

(1895) hydrographic map of Italy (Carta idrografica d'Italia) Civil engineering and industrial arts (L'Ingegneria civile e le arti industriali) $21, \mathrm{p} 79$

(1906) Inland navigation and railways (Navigazione interna e ferrovie) The technical monitor (Il Monitore tecnico) 12, p 248

(1905) Project of navigable canal lateral at Po river from Torino to Casale monferrato (Progetto di canale navigabile laterale al Po da Torino a Casale monferrato) The technical monitor (Il Monitore tecnico) 11, p 413

(1913) On the navigation line Milan-Venice (Sulla Linea di navigazione Milano-Venezia) The technical monitor (Il Monitore tecnico) 19, p 119

(1905) Proposal of an experiment of electric traction on canals in Italy (Proposta di un esperimento di trazione elettrica su canali in Italia) The technical monitor (Il Monitore tecnico) 11, p.252

(1905) Removable propeller for boats (Propulsore amovibile per battelli) The technical monitor (Il Monitore tecnico) 11, p.660 (1892) The Po and its hydrographic transformations in the province of Pavia (Il Po e le sue trasformazioni idrografiche nella provincia di Pavia) Journal of civil engineering department 20, p 433

(1905) The report of Commission of inland navigation in the Italy Kingdom on the problem of navigation in the Po Valley (La relazione della Commissione per gli studi della navigazione interna del regno sul problema della navigazione nella valle del Po) The technical monitor (Il Monitore tecnico) 11, p.531

(1928) The modern trends in the field of works for inland navigation in central Europe (Le moderne tendenze nel campo delle opere per la navigazione interna nell'europa centrale) Annals of public works (Annali dei lavori pubblici) 1928, p 463

(1906) The report of the commission appointed by the Board of Commerce for the study of improvements to the port dock of Ticinese district (Milan) (La relazione della commissione nominata dalla Camera di commercio per lo studio dei miglioramenti alla darsena di porta ticinese) The technical monitor (Il Monitore tecnico) 12, p 89

(1905) The consortium for inland navigation in the Padana valley (Il consorzio per la navigazione interna nella valle padana) The technical monitor (Il Monitore tecnico) 11, p.374

(1927) The protection of the embankments in the Pisa-Livorno navigation channel (La protezione delle sponde nel canale di grande navigazione Pisa-Livorno) Annals of public works (Annali dei lavori pubblici) 1927, p 1020

(1908) The financial question of inland navigation The Italian legislation and the Gianturco project (La questione finanziaria della navigazione interna La legislazione italiana ed il progetto Gianturco) The technical monitor (Il Monitore tecnico) 14

(1910) The effective action of the new ministry in theme of public works. The inland navigation in Italy (L'azione fattiva del nuovo ministero in materia di opere pubbliche. La navigazione interna in Italia) The technical monitor (Il Monitore tecnico) 16 


\section{Appendix C Monographs}

\begin{tabular}{|c|c|c|}
\hline $\begin{array}{l}\text { Beretta M, } \\
\text { Majocchi M (1914) }\end{array}$ & $\begin{array}{l}\text { On the arrangement of inland navigation ports with regard to their } \\
\text { importance and to rail or tram connections (Sulla sistemazione degli } \\
\text { scali e porti di navigazione interna avuto riguardo alla loro } \\
\text { importanza ed ai collegamenti ferroviari o tramviari) }\end{array}$ & $\begin{array}{l}\text { Milano: National } \\
\text { iAssociation of Navigation } \\
\text { Congresses }\end{array}$ \\
\hline Berni, A (1914) & $\begin{array}{l}\text { The Inland navigation in Padana plain and the international traffics } \\
\text { of central Europe (La navigazione interna nella Pianura Padana ed i } \\
\text { traffici internazionali della Europa centrale) }\end{array}$ & $\begin{array}{l}\text { Milano: National } \\
\text { Association of Navigation } \\
\text { Congresses }\end{array}$ \\
\hline Candiani, L (1906) & $\begin{array}{l}\text { The inland navigation in agricultural reports: communication } 3 \text { - } \\
\text { Fifth National Congress of Economic Societies (La navigazione } \\
\text { interna nei rapporti dell'agricoltura : comunicazione } 3 \text { Quinto } \\
\text { congresso nazionale delle società economiche) }\end{array}$ & Milano: Abbiati \\
\hline Candiani, L (1909) & Inland navigation and forest issue: conclusions & Bologna: Emiliano \\
\hline Ferro, G (1927) & Inland navigation (Navigazione interna) & Padova: Cedam \\
\hline Fazio, A (1904) & $\begin{array}{l}\text { The inland navigation and the railways of northern Italy (La } \\
\text { navigazione interna e le ferrovie del Nord dell'Italia) }\end{array}$ & $\begin{array}{l}\text { Roma: Polygraphic } \\
\text { publishing cooperative }\end{array}$ \\
\hline $\begin{array}{l}\text { Ministry of Public } \\
\text { Works (1924) }\end{array}$ & $\begin{array}{l}\text { Commission for the study of issues relating to navigation of the Po for } \\
\text { boats of at least } 600 \text { tons- Report and annexes (Commissione per lo } \\
\text { studiodelle questioni attinenti alla navigazione del PO per natanti di } \\
\text { almeno } 600 \text { tonnellate-Relazione ed Allegati) }\end{array}$ & Parma: Donati \\
\hline $\begin{array}{l}\text { Migliorini, E } \\
(1934)\end{array}$ & $\begin{array}{l}\text { Notes on inland navigation and traffic in Italian rivers and canals } \\
\text { (Appunti sulla navigazione interna e sul traffico nei fiumi e canali } \\
\text { italiani) }\end{array}$ & $\begin{array}{l}\text { Roma: Royal Italian } \\
\text { geographical society }\end{array}$ \\
\hline $\begin{array}{l}\text { Ministry of Public } \\
\text { Works (1931) }\end{array}$ & $\begin{array}{l}\text { Statistics of inland navigation on the waterways and lakes of Italy } \\
\text { Kingdom (Statistica della navigazione interna sulle vie navigabili e } \\
\text { laghi del Regno d'Italia) }\end{array}$ & $\begin{array}{l}\text { Roma: General Board of } \\
\text { State }\end{array}$ \\
\hline Mongini, G (1925) & $\begin{array}{l}\text { Inner navigation, derivation and irrigation in the province of Ferrara } \\
\text { (Navigazione interna, derivazione ed irrigazione nella provincia di } \\
\text { Ferrara) }\end{array}$ & Ferrara: Grossi \\
\hline Papi, G.U (1922) & The continental waterways in economic and administrative terms & Milano: Hoepli \\
\hline $\begin{array}{l}\text { Provincial } \\
\text { Committee of } \\
\text { Pavia (1914) }\end{array}$ & Direct communication between the Port of Genoa and the Po Valley & Novara: De Agostini \\
\hline $\begin{array}{l}\text { Royal railways } \\
\text { commission } \\
(1904)\end{array}$ & $\begin{array}{l}\text { Inland navigation: connection between railways and waterways } \\
\text { (Navigazione interna : raccordamento tra le strade ferrate e le vie } \\
\text { navigabili) }\end{array}$ & $\begin{array}{l}\text { Roma: Ripamonti e } \\
\text { Colombo }\end{array}$ \\
\hline Ruggiero, C (1927) & $\begin{array}{l}\text { Modern trends and directives in river arrangements for inland } \\
\text { navigation (Moderne tendenze e direttive nelle sistemazioni fluviali } \\
\text { per mavigazione interna) }\end{array}$ & $\begin{array}{l}\text { Padova:Typographic } \\
\text { Cooperative Society }\end{array}$ \\
\hline Sighieri, E (1927) & $\begin{array}{l}\text { Rivers, inland navigation, reclamations, ports (Fiumi, navigazione } \\
\text { interna, bonifiche, porti) }\end{array}$ & Pisa: Mariotti e Pacini \\
\hline Supino, C (1902) & $\begin{array}{l}\text { The inland navigation in relation to other means of transport (La } \\
\text { navigazione interna in relazione agli altri mezzi di trasporto) }\end{array}$ & Roma: Cecchini \\
\hline Valentini, C (1911) & $\begin{array}{l}\text { Inland navigation in Italy and abroad (La navigazione interna in } \\
\text { Italia e all'estero) }\end{array}$ & Bologna: Zanichelli \\
\hline $\begin{array}{l}\text { Vianello, C.A } \\
(1919)\end{array}$ & $\begin{array}{l}\text { Economic analysis of inland navigation (Analisi economica della } \\
\text { navigazione interna) }\end{array}$ & Roma: Poligrafica \\
\hline
\end{tabular}




\section{Appendix D}

Publications related to political and institutional initiatives

\begin{tabular}{|c|c|c|}
\hline Broggi, C (1909) & The Bertolini draft law on inland navigation & Genova: Marsano \\
\hline $\begin{array}{l}\text { Congress (House) of } \\
\text { deputies (1903) }\end{array}$ & $\begin{array}{l}\text { Inland navigation: about the motion presented by the deputy } \\
\text { Pantano and other colleagues ... / (La navigazione interna : a } \\
\text { proposito della mozione presentata dal deputato Pantano e da } \\
\text { altri colleghi .../) }\end{array}$ & $\begin{array}{l}\text { Roma: Typography of } \\
\text { deputies congress }\end{array}$ \\
\hline $\begin{array}{l}\text { Congress (House) of } \\
\text { deputies (1909) }\end{array}$ & $\begin{array}{l}\text { Discussion on inland navigation made to the Congress of } \\
\text { Deputies in the sessions on November } 23,24,25,26 \text { and } 27,1909 \\
\text { (Discussione sulla navigazione interna fatta alla camera dei } \\
\text { deputati nelle tornate del } 23,24,25,26 \text { e } 27 \text { novembre 1909) }\end{array}$ & $\begin{array}{l}\text { Roma: Typography of } \\
\text { deputies congress }\end{array}$ \\
\hline $\begin{array}{l}\text { Congress (House) of } \\
\text { deputies (1915) }\end{array}$ & $\begin{array}{l}\text { Draft law presented by the Public works minister (Ciuffelli) in } \\
\text { concert with the Treasury minister (Carcano) with the Finance } \\
\text { minister (Daneo) with the Navy minister (Viale) and with the } \\
\text { Agriculture and Commerce minister (Cavasola): execution of } \\
\text { inland navigation works and extension of deadlines ... session of } \\
\text { February 18, } 1915 \text { - (Disegno di legge presentato dal ministro } \\
\text { dei Lavori Pubblici (Ciuffelli) di concerto col ministro del } \\
\text { Tesoro (Carcano) col ministro delle Finanze (Daneo) col } \\
\text { ministro della Marina (Viale) e col ministro di Agricoltura } \\
\text { Industria e Commercio (Cavasola) : esecuzione di opere di } \\
\text { navigazione interna e proroga dei termini ... seduta del } 18 \\
\text { febbraio 1915) }\end{array}$ & $\begin{array}{l}\text { Roma: Typography of } \\
\text { deputies congress }\end{array}$ \\
\hline Frizzoni, G (1905) & $\begin{array}{l}\text { For inland navigation in the Po valley, according to the studies } \\
\text { and projects of the government commission and in relation to } \\
\text { the advantages it may bring to the province of Bergamo }\end{array}$ & $\begin{array}{l}\text { Bergamo: Italian institute of } \\
\text { graphic arts }\end{array}$ \\
\hline $\begin{array}{l}\text { Italy Kingdom Senate } \\
(1910)\end{array}$ & $\begin{array}{l}\text { Discussion on inland navigation made to the Senate of Kingdom } \\
\text { in the session of December 21, } 1909 \text { (Discussione sulla } \\
\text { navigazione interna fatta al Senato del Regno nella tornata del } \\
21 \text { Dicembre 1909) }\end{array}$ & Roma: Forzani \& C \\
\hline $\begin{array}{l}\text { Senate of the Kingdom } \\
\text { of Italy (1914) }\end{array}$ & $\begin{array}{l}\text { On inland navigation: interpellation of Senator Arnaboldi made } \\
\text { in the session of June } 15,1914\end{array}$ & $\begin{array}{l}\text { Roma: Typography of } \\
\text { senate }\end{array}$ \\
\hline $\begin{array}{l}\text { Ministry of Public } \\
\text { Works (1903) }\end{array}$ & $\begin{array}{l}\text { Acts of Commission for the study of inland navigation in Po } \\
\text { valley (Atti della Commissione per lo studio della navigazione } \\
\text { interna nella Valle del Po) }\end{array}$ & $\begin{array}{l}\text { Roma: Typography of } \\
\text { deputies congress }\end{array}$ \\
\hline $\begin{array}{l}\text { Ministry of public } \\
\text { works (1904) }\end{array}$ & $\begin{array}{l}\text { Commission for inland navigation (Commissione per la } \\
\text { navigazione interna) }\end{array}$ & $\begin{array}{l}\text { Roma: Ripamonti e } \\
\text { Colombo }\end{array}$ \\
\hline $\begin{array}{l}\text { Ministry of public } \\
\text { works (1931) }\end{array}$ & $\begin{array}{l}\text { The inland navigation of northern Italy, 15th International } \\
\text { Navigation Congress, Venice, September } 1931 \text { (La navigazione } \\
\text { interna dell'Alta Italia, } 15 \text { Congresso internazionale di } \\
\text { navigazione,Venezia,settembre 1931) }\end{array}$ & $\begin{array}{l}\text { Roma: General Board of } \\
\text { State (Provveditorato } \\
\text { generale dello Stato) }\end{array}$ \\
\hline $\begin{array}{l}\text { Moschini, A, Paratore, } \\
\text { G (1907) }\end{array}$ & $\begin{array}{l}\text { The draft law on inland navigation November 27, } 1906 \text { n. 542: } \\
\text { Observations and proposals (Il disegno di Legge sulla } \\
\text { navigazione interna, } 27 \text { novembre 1906, n } 542 \text { : Osservazioni e } \\
\text { proposte) }\end{array}$ & $\begin{array}{l}\text { Padova:Typographic } \\
\text { Cooperative Society }\end{array}$ \\
\hline Niccolini, P (1909) & $\begin{array}{l}\text { On inland navigation: discourse of deputy Pietro Niccolini } \\
\text { pronounced at the congress of deputies in the session of } \\
\text { november } 24,1909 \text { (Sulla navigazione interna : discorso } \\
\text { dell'onorevole Pietro Niccolini pronunziato alla Camera dei } \\
\text { deputati nella tornata del } 24 \text { novembre } 1909\end{array}$ & $\begin{array}{l}\text { Roma: Typography of } \\
\text { deputies congress }\end{array}$ \\
\hline
\end{tabular}




\section{Copyrights}

Copyright for this article is retained by the author(s), with first publication rights granted to the journal.

This is an open-access article distributed under the terms and conditions of the Creative Commons Attribution license (http://creativecommons.org/licenses/by/4.0/). 